\title{
Institutional entrepreneurship Agents' ability and activity for building up new institutions by combining existing elements ${ }^{1}$
}

\author{
Katalin Szabó \\ Professor, Department of Comparative and Institutional Economics, Corvinus University \\ Budapest \\ Email: katalin.szabo@uni-corvinus.hu
}

The rapid institutional changes taking place today, including the emergence and global spread of new institutions bring to the fore the question of how new institutions develop. From the 1990s onwards, a new technical term has begun to spread in the literature: institutional entrepreneurship, reflecting the revaluation of people's activity in institutional change. The aim of the paper is to answer the questions regarding this kind of entrepreneurship. How does institutional entrepreneurship emerge, how can we interpret and define this phenomenon? What kind of driving forces are behind it? How does it work in the real economy? The novelty of the paper is in addressing institutional entrepreneurship as the result of a special ability and activity of actors to combine different, already known elements for building up new institutions. The study introduces the characteristics of institutional entrepreneurship, using the example of the sharing economy, by contrasting sharing as an alternative to conventional market solutions. The paper also demonstrates how the institutional entrepreneurship of sharing changes its socioeconomic environment, from mobilization of unused resources through perception of ownership to the increase of the growth potential of the economy.

JEL-codes: L26, M 13, O31

Key words: Institutional entrepreneurship, non-isomorphic change, agency theory, institutional proliferation, sharing economy, sharing as a combination, dematerialization, mass customization.

\section{Introduction}

The objective of the present study is to show institutional entrepreneurship from a nonconventional perspective as creating innovative connections between, or new combinations of existing institutions. Shane and Venkataraman (2000: 218) define entrepreneurship as such by

\footnotetext{
${ }^{1}$ This paper is an extended version of the presentation given at the conference held on the occasion of Balázs Hámori's $70^{\text {th }}$ birthday by the Department of Comparative and Institutional Economics of Corvinus University Budapest.
} 
answering the questions: "why, when, and how opportunities for the creation of goods and services come into existence; why, when, and how some people and not others discover and exploit these opportunities, and why, when, and how different modes of action are used to exploit entrepreneurial opportunities". In this paper we raise similar questions, with regard to a special kind of entrepreneurship. How does institutional entrepreneurship emerge? What drives this type of entrepreneurship? How does it work in practice? What impact does it have on its socio-economic environment?

Institutional entrepreneurship can be defined as "the purposive action of individuals and organizations aimed at creating, maintaining and disrupting institutions" (Lawrence - Suddaby, 2006: 215) Here we leave out of consideration the formal institutions (law, regulations, etc.) created by the conscious acts of governmental players or other state actors. We focus in this paper on institutional entrepreneurship as a purposeful act of market players or other non-state actors. Though the number of articles and books devoted to the issue has been rapidly increasing, researchers are far from reaching a consensus about the basic concepts and interpretation of the phenomenon. Thus it is quite opportune to clarify some of the disputable concepts or problems in our study. In response to the issue of institutional entrepreneurship, discussed in the literature, we approach the phenomenon from a special angle. The novelty of the paper is that it treats institutional entrepreneurship as a result of a special ability and activity of actors to combine already existing resources and institutional elements for building up new institutions. The study describes the characteristics of institutional entrepreneurship, using the example of the sharing economy, by contrasting them as alternatives to current conventional market institutions. ${ }^{2}$

\section{Institutional entrepreneurship, institutional entrepreneurs.}

Before we come to the issue, we should define the essence of some basic notions occurring in the paper: namely institution and entrepreneurship, both having different understandings and

\footnotetext{
${ }^{2}$ Conventional market institutions mean, in this context, the different kinds of profit-oriented capitalist enterprises, from multinational companies to SMEs.
} 
definitions in the literature. In this paper we basically apply the Northian definition of institutions: "Institutions are the rule of the gamein a society, or more formally humanly devised constraints, that shape human interactions. In consequence, they structure incentives in human exchange whether political, social, or economic" (North 1990: 3). The other crucial notion in our work is the entrepreneur. We use the concept of entrepreneur or entrepreneurship in a Schumpeterian sense: "to Schumpeter the entrepreneur is the innovator who implements change within market through the carrying out of new combinations" (Dean 2016: 28). Similarly to entrepreneurship in general, the combination of different elements and resources constitutes the core of institutional entrepreneurship too. The Schumpeterian definition of entrepreneur is especially adequate for the subject of our paper, because the combination of the existing elements in an innovative way plays an essential role in institutional entrepreneurship too.

Institutional economics had, for a long time, focused mainly on the analysis of a stable institutional framework, and on the actors' adaptation to this framework. It presented economic players as embedded in the institutional network who consider this framework as given. "In sum, the institutional literature, whether it focuses on economics, sociology or cognition, has largely focused on explaining the stability and persistence of institutions as well as isomorphic change in fields. More recently, however, there has been interest in how non-isomorphic change can be explained using an institutional lens" (Garud et al. 2007: 959). There were also scholars who addressed the problem in a dynamic way, analyzing and explaining the transformation of institutions. First of all, the works of Hayek (1988), North (1990) and Nelson (2005) should be mentioned in this context. ${ }^{3}$ But while explaining the institutional changes, they left in the shadow or even denied the active role and conscious efforts of actors in institutional evolution. Hayek ignored the role of conscious and purposeful human actions and intentions in the institutional changes or in the evolving complexity of institutions, which he termed "spontaneous order."

To understand our civilisation, one must appreciate that the extended order resulted not from human design or intention but spontaneously: it arose from unintentionally conforming to certain traditional and largely

\footnotetext{
${ }^{3}$ There are of course numerous other explanations (see Brousseau et al. 2011; Kingston - Cabarello 2009), but the discussion on them would go beyond the limits of our paper.
} 
moral practices, many of which men tend to dislike, whose significance they usually fail to understand, whose validity they cannot prove, and which have nonetheless fairly rapidly spread by means of an evolutionary selection - the comparative increase of population and wealth - of those groups that happened to follow them. (Hayek 1988: 6)

North (1990) made a distinction between the formal and informal rules regarding their role in institutional changes. According to him, informal rules are shaped in an evolutionary process, and play a key role in institutional change, because they have transformed slowly and cannot be changed deliberately. Similarily to Hayek, Nelson (2005) also saw institutional changes as a result of evolutionary forces, but he considered physical technology as the main driver of institutional transformation. Oliver Williamson $(1975 ; 1985)$ treated the institutional framework as exogenous, underlining the role of transaction and transformation costs in the development of new institutional forms. The common characteristic of the above explanations of institutional change is that they neglected the role of conscious human activity in creating new institutions or in their evolution. "Whereas early institutional studies (Selznick 1949; 1957) did account for actors' agency, subsequent institutional studies tended to overlook the role of actors in institutional change. According to these latter studies, institutional change was caused by exogenous shocks that challenged existing institutions in a field of activity" (Leca et al. 2008: 3).

"The notion of institutional entrepreneurship emerged as a possible new research avenue to provide endogenous explanations for institutional change" (Leca et al. 2008: 3). In the past few decades, researchers, especially those primarily interested in the theory of the firm and organizational studies, started to shift the focus and look at the other side of the coin when analyzing institutions. "The hallmark of institutional entrepreneurship is associated with the importance, given to the actors choices, perception, and actions in the context of change" (Drori - Landau 2011: 21). At the same time, the passivity of actors has been resolved in the analyses, focusing on the generators of change. "Institutional entrepreneurship tends to elevate the hypermuscular, heroic efforts of entrepreneurial actors, who overthrow established institutions; it offers a counterpoint to alternative conceptualization of actors as 'passive dopes', who are overwhelmed and constrained by and thus succumb to, institutional forces without hope of overthrowing or even changing them" (Raffaely - Glynn 2015: 408). The new approach puts the 
stress on actors' activism, and it has become known as agency theory ${ }^{4}$ in economic literature of the late 1980s (DiMaggio 1988).

It is not by coincidence that institutional entrepreneurship and institutional entrepreneurs have come to the focus in the past few decades. In a knowledge-based economy, activity and its subject is in general valued more than conformity and the passive acceptance of existing frameworks, just as much in practice as in theoretical research. Seeing the growing research interest in agency theory, and the rapidly increasing literature ${ }^{5}$ on institutional entrepreneurship, many scholars consider this branch of institutionalism the most promising line for developments of institutional theory (see e.g. Greenwood et al. 2002; Tracey et al. 2011; Laksman 2015; Hu et al. 2016). But we also share the opinion of Laksman: "despite advances in the institutional entrepreneurship literature (e.g., DiMaggio 1988), our understanding of the dynamics of institutional change is in its infancy." (Laksman 2015: 160) This explains the lack of consensus in definition and the absence of a common conceptual framework of institutional entrepreneurship, and opens a broad space for further researches in this direction.

\section{Institutional entrepreneurship: the relevance of the problem in the recent}

\section{era}

In the introduction we described institutional entrepreneurship as "the purposive action of individuals and organizations aimed at creating, maintaining and disrupting institutions" (Lawrence - Suddaby 2006: 215). As to the concept of institutional entrepreneurship, we consider it necessary to enrich the generally accepted definition of the term. According to our extended definition, institutional entrepreneurship may be characterised as the purposive action of individuals or groups operating in (or outside the scope of) market and organisations, which action is aimed at the establishment of new institutions (substantial restructuring, and abolishment of old institutions, in other words, institutional innovation). "Institutional

\footnotetext{
${ }^{4}$ On agency theory, see Leca et al. (2008).

${ }^{5}$ Between 1998 and 2017, the EBSCO database contained altogether 350 records regarding institutional entrepreneurship. Whilst in the first decade of the above mentioned period (between 1998 and 2007) the records amounted only to 55, in the last decade, they were already 295 . Google yielded 60,600 hits on this entry.
} 
entrepreneurship is not localised, but rather it takes place on a large scale" (Raffaely - Glynn 2015). It is an important element of the definition that institutional entrepreneurs "create a whole new system of meaning that ties the functioning of disparate sets of institutions together" (Garud et al. 2002: 196).

Institutional changes are closely intertwined with organizational changes. Although institutional entrepreneurs in most of the cases disrupt or change the existing organizational framework, this kind of entrepreneurship is not confined to creating new types of organization. It is a much more comprehensive notion. As Bockhaven et al. (2005: 175): put it: "Institutional entrepreneurship targets entire fields, the overall networks, cultural-cognitive systems, organizational archetypes, and collective action repertoires [...]". ${ }^{6}$ The just-in-time method or teamwork are simple organizational innovations, but these do not meet the criteria of institutional entrepreneurship, they do not "target entire fields, the overall networks, cultural-cognitive systems, organizational archetypes, and collective action repertoires". Institutional entrepreneurship is a starting point for major socio-economic changes that transform the whole industry or even the world.

In an historic era when we are witnessing genuine institutional explosions, the relevance of research focusing on institutional entrepreneurs does not need to be vindicated. "We theorize that these moments of transition, from one historical period to the next, are times when institutional stability and isomorphism may be somewhat weakened and institutional innovations may play a greater role" (Raffaely - Glynn 2015: 411). The phenomenon of institutional proliferation, i.e. fast spread of novel institutional models to other sectors, areas, or countries, has also become a general tendency. E-markets for example exist in almost every country. EBay, the archetype of the e-market, shows clearly the crucial role of the institutional entrepreneur: the name of the initiator, Pierre Omidyar, is well-known. Its Hungarian equivalent called Vatera, founded in 2000, is also a successful enterprise, but we can find e-Bay's local counterparts also in less developed countries, such as, for example, the Ethiopian e-market called Ethiopian Artisan, dealing artisanal products.

\footnotetext{
${ }^{6}$ In this regard the authors refer to the article of DiMaggio and Powell (1983) and the book of Scott (2008).
} 
Naturally, institutional entrepreneurships were founded in every era. The classic example for this is the founding of the Dutch East India Company in 1602. The Dutch East India Company was the first entrepreneurship to issue stock, contributing to the birth of the stock exchange, a substantial institution of capitalism till the present day, which changed radically the nature of capitalism. So, the founders of the Dutch East India Company, who played an active role in these major changes, may be considered institutional entrepreneurs, just like the establishers of conglomerates in the 1960s and 1970s. In the 1960s and 1970s novel market players in America organized many small companies with relatively small market shares and very diverse company profiles into huge enterprises, which also meant the creation of conglomerate, an organization that had not existed before. "Often little conglomerates would take over giant, cash rich companies, many times their own size, using in the end the cash of the company taken over to pay for the acquisition. Thirty-year-old whiz kids pyramided thousands of dollars into tens of millions almost overnight" - wrote Samuelson in his textbook Economics (1976: 528). "Often those seeking take-overs represented outsiders self-made newly arrived chaps, who hadn't belonged to Yale's Skull and Bones or been vetted by the existing business establishment" (Samuelson 1976: 529) This innovation made it possible for outsiders lacking substantial financial means to engage in a competition with powerful monopolies and oligopolies, thus shaking up frozen ownership structures. These founders of conglomerates may legitimately be considered institutional entrepreneurs, since they did not fit into the existing business and institutional order, but rather went around it through establishing a novel institution.

Nowadays, however, new institutions appear in vast numbers and spread fast around the globe. This is the reason why the analysis of institutional entrepreneurship has become a popular line of research. The relevance of the topic of institutional entrepreneurship in present day Hungary is further increased by the currently started fundamental institutional restructuring of the country, with the establishment of several new institutions. The institutional changes go on not only in the governmental sphere, but also in the market. However, radical institutional restructuring may be detected elsewhere, too (ee may refer here to changes taking place in the European Union following Brexit). 
There are many different forms of institutional entrepreneurship, but they show some common characteristics too. Similarly to a traditional entrepreneur, an institutional entrepreneur also faces constraints in the form of a variety of institutional barriers. A typical common type of such barriers is entry barriers, due to the monopolization of the targeted industry or constraints created artificially by the government. Because of the strength and power of incumbents, there is no other way to overcome these barriers, only by disrupting 7 the given institutional frameworks and creating new ones. New technologies often do not fit traditional institutional frameworks, and this induces people who are interested in new technologies, and want to turn them into a business success to disrupt the persistent institutional frameworks. But the incumbents often resist institutional changes. Insistence on traditional operational modes by incumbents is explained not only by their natural conservativism, but also by the phenomenon of sunk costs. Nevertheless, in some cases the incumbents do not notice the appearance of dangerous competitors, and by the time they realize the danger, the institutional entrepreneurs have acquired a considerable market share, starting to even force them out of the market. As mentioned earlier, this was typically observable for example in the case of conglomerates.

Both the entrepreneur and the institutional entrepreneur generate externalities for others, but in the first case the externalities come from a technology, a product, or a business model, whilst in case of institutional entrepreneurs the externality is embodied in a new, more efficient institution, which gives the opportunity for the society to utilize inactive or under-used resources (Garud et al. 2007). This statement was proved by the historic examples too. The Dutch East India Company, for example, put in motion small capitals, which separately were unable to finance big projects of conquering Asia, ensuring the dominance of the highly profitable longdistance trade. Institutional entrepreneurship dynamizes a considerable part of the economy and has a positive effect on the growth potential of the industry, a country or even the world economy. Institutional entrepreneurship improves the general efficiency of the economy by crowding out the old, obsolete institutions, which hinder developments. As a consequence it clears the way before technological and other innovations. Most of the novel institutions created

\footnotetext{
${ }^{7}$ The phenomenon of disruption was thoroughly analyzed in the context of innovation by Christiansen $(1997 / 2013)$ in his seminal work.
} 
by institutional entrepreneurs decrease the transaction costs and ensure greater flexibility in business transactions. These are the biggest trumps in the competition with their counterparts.

The novel institutions created by institutional entrepreneurs often change the perception of ownership, too. This was also clearly proved by the case of the conglomerates, because the founders of conglomerates built whole company empires in lack of own property or investment capital. The above characteristics of institutional entrepreneurship may constitute enough reasons for us to turn to observing the character of institutional entrepreneurship and entrepreneurs, using the example of typical institutional entrepreneurship: the sharing economy. We are convinced that the case of a real institutional entrepreneurship can better enlighten the nature of the phenomenon than an abstract explication of the issue.

\section{The method of the study}

The paper uses qualitative methods. As we do not have extensive and reliable ${ }^{8}$ databases of different kinds of institutional entrepreneurship, among them of sharing, which would allow us to statistically capture the phenomena discussed in the paper, no other methodology but qualitative analysis can come into play. Partial studies, statistical analyses taken out of context, of course exist, however, the results are far from being apt for generalization.

Looking at the sharing based economy we focus on one relationship: we describe and analyze the new phenomenon as a combination of old and new elements in different senses. Thus, we return to the Schumpeterian tradition in this sense. An important part of the study is the theoretical analysis and comparison. We contrast sharing as alternatives to current conventional market institutions.

\section{The institutional entrepreneurship of sharing}

One of the most spectacular and robust forms of institutional entrepreneurship in the last one or two decades is sharing. Institutional entrepreneurs play a decisive role in the phenomenon of

\footnotetext{
${ }^{8}$ In some cases the fact that they originate from data providers who themselves have an interest in the results shown by the statistics, also reduces the value of these statistics.
} 
sharing for several reasons. Sharing is a radically novel institution, whose initiators may be easily identified. In addition to this, sharing definitely meets the criteria of institutional entrepreneurship as described in Section 3: it has spread fast, has had a deep and wide impact, and has had a global dimension from the beginning. Showing disruptive signs, it threatens several traditional industrial branches from transportation to the catering and hotel industry to flat rentals.

\subsection{Interpretation of sharing and its two basic forms}

Sharing can be defined as "peer-to-peer based activity of obtaining, giving, or sharing the access to goods and services, coordinated through community-based online services. " (Hamari et al. 2016: 2047) The institution of sharing is an umbrella concept, incorporating different versions of the principle of sharing - from communities operating on purely community based principles, where participants only share the costs of the usage of their shared goods.

The sharing economy encompasses a wide range of initiatives from marginal twist to business as usual (BAU) to radical alternatives. We use the term connected consumption to describe the initiatives in the sharing economy from the consumer side. Nostalgia about an earlier era when people knew their neighbors and could rely on them, permeates the sharing economy. Connected refers to both the digital and the social aspects of these practices. Meanwhile, from the provider's side, these innovations open up a variety ways to earn income and/or increase access to goods and services. (Dubois et al. 2014: 51)

Confusingly, numerous phenomena and concepts closely related to sharing appear in the literature, whose definition is not yet agreed on by the researchers. To mention just one example, we may come across the term "collaborative consumption", or, in other words, "connected consumption", besides sharing. Applying this terminology, researchers mean to shift the focus from service providers to those using the services when looking at the phenomenon of sharing. Yet others refer to this as pure sharing, void of any business interest, and define it as follows: connected consumption, where participants share goods mostly eliminating money or any business interest, constitutes a classical community based solution (Botsman - Rogers 2011). Favor banks operate on this principle, the most well-known Hungarian example being “OurStreet” (Miutcánk). The terms "peer to peer economy”, "pay as you use economy" or 
"access economy" are also used; there are subtle differences as to their meaning, but these terms are also sometimes used to refer to somewhat different versions of sharing. ${ }^{9}$

In our paper we make a definite distinction between the two basic forms of sharing, the "pure sharing", that works without any profit or business considerations, and the mixed version of sharing, which uses the potential of mass (community), but driven by business interest from the intermediary's side. Some authors definitely separate these two forms from one another, and the latter form, namely the mixed version (like Uber or Airbnb) organized by intermediaries they do not consider as sharing. "When 'sharing' is market-mediated — when a company is an intermediary between consumers who don't know each other -- it is no longer sharing at all. Rather, consumers are paying to access someone else's goods or services for a particular period of time. It is an economic exchange, and consumers are after utilitarian, rather than social, value.... isn't really a 'sharing' economy at all; it's an access economy." (Eckhardt - Bardh 2015: 3, 2) We focus in the paper mainly on this latter, mixed version of sharing.

Nevertheless, there are instances when a situation cannot be efficiently solved, either by the market or by the state - in these cases pure sharing solutions constitute the best alternative. For example, opening and maintaining day care establishments for infants in small villages may not be profitable, nor does the state necessarily have sufficient resources or willingness to do it. In these cases the community of the parents involved may join forces and come up with a solution. Building on mutual trust, they use the resources of the local community looking after each others' children.

In part, pure collective forms of the sharing economy offer a solution for such and similar problems, as originally analysed by Elinor and Vincent Ostrom (1977). Ostrom conceptualised this as a "common pool resources problem", ${ }^{10}$ and, although this is a phenomenon different from pure sharing in many respects, the two do have characteristics in common. In the case of the infants nursery organized by a local community - as opposed the common pool resources - the

\footnotetext{
${ }^{9}$ However, the establishment of a sharing taxonomy exceeds the scope of this paper.

${ }^{10}$ Ostrom and her co-workers added "a very important fourth type of good - common-pool resources - that shares the attribute of subtractability with private goods and difficulty of exclusion with public goods" (Ostrom - Ostrom 1977). "Forests, water systems, fisheries, and the global atmosphere are all common-pool resources of immense importance for the survival of humans on this earth" (Ostrom 2009: 412) .
} 
exclusion from the service is a real option Nevertheless, this sharing solution is reflected perfectly by Ostrom's statements: "Extensive empirical research documents the diversity of settings in which individuals solve common-pool resource problems on their own, when these solutions are sustainable over long periods of time, and how larger institutional arrangements enhance or detract from the capabilities of individuals at smaller scales to solve problems efficiently and sustainably." (Ostrom 2009: 435).

At the time of its emergence people started to hype sharing, since they regarded it as a community alternative to capitalist solutions, the overture of a new social system. As Morgan and Kuch (2015: 557) put it: "The notion of a sharing economy, as the phrase itself suggests, has connotations that are more nurturing and generative than extractive, as reflected in the subtitle of Janelle Orsi's pioneering book on Practising Law in the Sharing Economy: 'helping people build cooperatives, social enterprise, and local sustainable economies." Jeremy Rifkin (2014) analyzing the sharing economy - envisioned a world beyond markets, where we would live in an increasingly interdependent global Collaborative Commons. Similarly was the essence of the sharing formulated by Gibson-Graham (2003: 5), describing it as "a need to modify ourselves, to become different, and more specifically [to develop] the capacity to enact a new relation to the economy." We do not agree with the above standpoints. But, we also refuse the other extreme, according to which there is no novelty in sharing, it should be considered "business as usual". There are such opinions that sharing should be considered merely as a digitalized marketplace that technically makes the meeting of supply and demand easier. Indeed, meeting supply and demand is not an element that emerged within the sharing economy, on the contrary, the existence of the institution of exchange dates back to prehistoric times. Occasional exchanges made between tribes, however, can be paralleled neither with the agora in Athens nor with today's global markets, despite the fact that in all of the above the meeting of supply and demand was realised. However, they do differ in numerous other aspects, as we will illustrate in Table 2 when comparing today's conventional capitalist entrepreneurship and sharing economy. We see mixed sharing, discussed in this paper as a combination of collaborative common and conventional business solutions. 


\subsection{Active role of institutional entrepreneurs in inventing and diffusion of sharing}

A typical example for the above mixed sharing is Uber, an alternative to the conventional market solution of a taxi. The sharing cases underpin the role of institutional entrepreneurs in initiating of new institutions, as we have underlined it in Section 2. We can identify for example the initiator of the sharing service of Uber:

In 2008 Travis Kalanick and Garrett Camp, like old pals, were complaining... how hard to find a cab when they are packed with luggage under the rain and no taxi seems to pass. They were about ways to solve the issue of finding cars at the right place, on the right time... Garrett took the lead and engineering a mobile app for the iPhone that would revolutionize the very idea of getting around. Travis joined the ride to work with him on what would later be known as Uber. Fast forward to January 2010 and Uber was already rolling a couple of black cars in the city of New York (Belarbi n.d.).

Uber may also be regarded as an example of how institutional entrepreneurship may shake up rigid market structures, in this case that of passenger transportation. The taxi market is characterised by rigidity in most countries. Kalanick and Camp did not only carry out an organisational reform but they managed to break the conventional institutional framework that used to make the taxi market difficult to enter for outsiders. With their institutional entrepreneurship they went around the entrance barriers/requirements, just like the "inventors" of conglomerates four decades earlier. Rather than entering the field of the incumbents, and thus starting a hopeless battle, the inventors of Uber decided to establish a new battlefield out of the control of the incumbents.

Not only organizers but also users of institutional entrepreneurship belong characteristically to younger generations. This, however, also foreshadows the future, according to the results of a research carried out by Bloomberg. The study shows the representation of age groups related to the total workforce of the United States, the ratio of the given age group in total workforce indicated in blue, while the ratio of the age group working in the sharing economy indicated in orange. As seen in Figure 1, the representation of the age group 65+ working in sharing economy amounts to only 1-2 percent of the total of those working in the sharing sector, while the ratio of those between 18-24 years of age amounts to 39 percent, despite the fact that this latter age group represents only 12 percent of the total workforce of the United States. 
Figure 1. Sharing economy workers by age group in the US (2015)

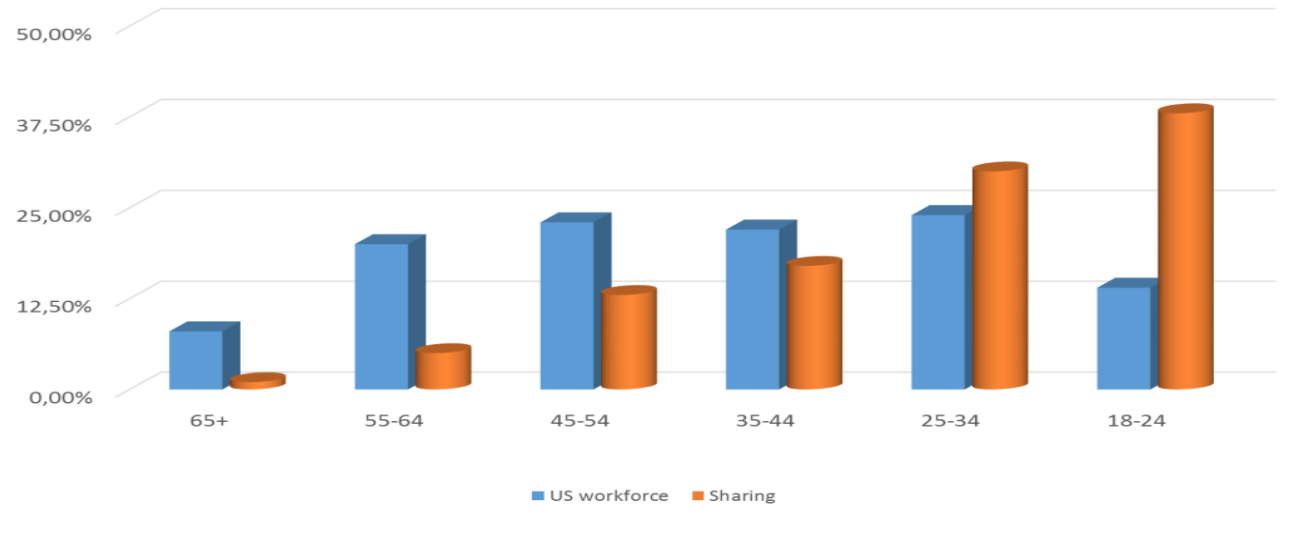

Source: 2015 Economy Workforce Report.

\subsection{The technological background: the combination of known technologies}

The institution of sharing also existed earlier, but it was not widely known. The digital revolution and the spread of info-communication technologies did not only make sharing much more popular and widespread but also modified its character, making it possible to target a considerably greater community. It need not be emphasized that present day solutions classifiable as belonging to the so called sharing economy could not have emerged without the internet and development of mobile communication technology (smart phones, applications, internet platforms, etc.). We tend to forget that significant institutional entrepreneurships in the past $^{11}$ did also rely to a great extent on infocommunication technologies of the given era.

Information technology occupies a central role in the forms of sharing in the $21^{\text {st }}$ century. The services available are not only economical, but also comfortable, suited to personal needs (mass customization), which, in case of Uber and service providers of a similar profile, are created with

\footnotetext{
${ }^{11}$ For example, in 1880, the German social security system, an institutional entrepreneurship of national scale could not have come into existence in the absence of information technology developments of the age. In order to introduce social security, bureaucracy had to keep track of citizens, complex data had to be collected and stored (typewriter, cheap paper, development of the German postal service, professional German bureaucracy Shiller 2005).
} 
the help of mobile apps and coordinating internet platforms. The current variations of sharing economy may be defined as combinations in the technological sense too, the unification of physical goods (car, room, tools, etc.) and ICT technology. One is useless without the other. We are talking about a new combination, every element of which existed before; it is only their innovative combination that can be regarded as revolutionary.

Printing is often cited as a classical example for this phenomenon. "Johannes Gutenberg, the creator of printing press, utilized movable types, combined two previously unconnected items the winepress and the coin pouch - to create an unprecedented invention that would make printed books for millions of people" (Noble Topf 2014: 85). It is not difficult to recognize that the development of capitalism may not have taken place without Gutenberg's institutional entrepreneurship.

The pace of work of the monks drawing letters with scrutiny into codices could have never been suitable either for the edition of volumes of technological descriptions, or for the supply of textbooks for mass vocational training, or the mass production of newspapers. Without the latter, modern industrial sociopolitical framework could not have come into existence. Without pamphlets and newspapers reaching broad masses (of by the time literate people) industrial capital could never have overcome the static rule of landlords. Similarly, a couple of hundred years later, on the turn of the 20th century transnational companies could not have come about without the operation of the telephone or the telegraph (Szabó Hámori 2006: 46).

The far-reaching effect of Gutenberg's institutional entrepreneurship clearly shows the difference between simple technological innovation and institutional entrepreneurship.

\subsection{Sharing as a combination in different senses}

As we pointed out in the paper, we handle the institutional entrepreneurship of sharing as a combination of existing elements in many different senses. One can meet in the literature other approaches, that also put the stress on the combinative character of sharing, but they interpret it as one side of the combination, as the basis of a future new society, which has not yet been combined with the capitalist market economy. Jeremy Rifkin (2014) sees the economy of our days as a combination of the business world and collaborative economy of sharing. He has 
predicted that the collaborative economy incrementally may crowd out the capitalist market economy. The people will share tangible and intangible goods on the Internet. In such a world, ownership and "market value" will be replaced by "sharable value" in the Collaborative Commons. We provide a totally different meaning for combination in the context of sharing. In our interpretation, sharing itself (at least some specific kinds of sharing) is a combination. Take, for example, Uber and Airbnb. The institutional entrepreneurship of sharing may be conceived as the combination of the common use or collaborative consumption of goods and business intermediaries, connecting supply and demand. In other words, it is the combination of the novel, shared use of goods and traditional capitalist profit-oriented services.

The institutional entrepreneurship of sharing is a complex phenomenon, combining more different institutions or solutions already known. The institution of mass customization (Szabó Kocsis 2002), for example, exists independently from sharing, but it is also a building block for this type of entrepreneurship. The services of Uber or Airbnb show the characteristics of massification, but at the same time they adjust to the individual unique needs of every single customer. The wide spread of customization and personalization may also be traced back to the appearance of ICT technology. The demand for uniform mass services has been decreasing, while people are attracted by the great variety of services available. Through the amazing variety of their supply, global service providers of sharing economy are able to provide much bigger space for personalization than their traditional counterparts.

The shift towards dematerialization in many segments of the economy is one of the most robust trends of the last decades, and this trend is present also in sharing. People's willingness to temporarily access goods, to have the function instead of having the goods, the "access over property" principle is an inbuilt element of sharing. It is not by accident that functions rather than material products are in the focus of sharing attempts. People need a hole in the wall rather than a drilling machine, mobility rather than a car, accommodation rather than a weekend house. This effort is in line with the knowledge economy currently becoming more and more dematerialized. Nevertheless, market players operating in the field of production of goods still want to sell cars and do artificially incorporate into their household appliances parts that make the appliances obsolete ten years later, so that the manufacturer can sell the same products to the 
same consumers again. This is how a market niche appeared for those institutional entrepreneurs who offer selling functions rather than goods to consumers. Table 1 summarizes the different types of combinations which determine the institutional entrepreneurship of sharing.

Table 1. Institutional entrepreneurship (sharing) as a combination of business and collaborative solutions*

\section{Type of combination}

Built on the combination of different technologies or goods already known

Combination of new types of actors, and conventional market players

Combination of several institutions already known elsewhere

Combination of new types of atypical employment and reliability of service

Combination of different driving forces, which direct consumer demand towards the sharing entrepreneurships

\section{Example of Uber and Airbnb}

Technological combination of mobile application, internet platform (intangible goods) and different types of tangible goods (car or accommodation)

The combination of the "mass" (community), sharing their resources and profit oriented intermediary company

Mass customization of the service for individual consumers, buying functions instead of goods, electronic flee market, etc.

Combination of flexible, fragmented, individual employment possibilities for service providers and fixed, safe service, organized by a profit-oriented company

Unsatisfactory services of conventional monopolist service providers and the budgetary constraints of consumers

Source: compiled by the author

\section{The socio-economic effects of sharing}

\subsection{Mobilization of resources and decreasing amount of waste: external effects of sharing}

As mentioned in Section 3, institutional entrepreneurship in most cases mobilizes unutilized or underutilized resources (DiMaggio 1988). The institutional entrepreneurship of sharing makes the emergence of such transactions possible that could never have been realized in the traditional institutional framework. "On average, the capacity utilization rate is 30 percent higher for UberX drivers than taxi drivers when measured by time, and 50 percent higher when measured by miles." (Cramer - Krueger 2016: 177). 
Sharing is aimed at services and goods that would otherwise be unaffordable for the average consumer. "The practical interest [for sharing] has been driven by a combination, on the one hand, of less than satisfactory experience with managerial and contractualist nostrums for service delivery and, on the other hand, of increasing budgetary stringency (OECD 2011) as it was generally summarized as how to govern the commons when both government and private markets fail" (Afford 2014: 300). The budgetary problems of consumers have been more severe from 2007 as a consequence of the world economic crisis. A similar effect is achieved by the increasing income inequalities in most countries of the world on the diffusion of cost-saving sharing.

An apt example for resource mobilization is Oszkar Telekocsi, a community-based alternative to taxi services, founded in Hungary. Not everyone can afford daily mobility using their own personally owned vehicle, moreover, many of those who do own a car prefer to share its maintenance and fuel costs with others, if they belong to a lower income group. The welfare enhancing effects of sharing may therefore hardly be overestimated. The comment of a member of the Hungarian Oszkar carpooling community is a typical example for this. A grandmother living in the countryside could only visit her grandchild once a month due to high travel expenses, but thanks to Oszkar ridesharing they may now see each other much more often.

However, not only the material resources are mobilized by sharing, but also the human resources as we experience in case of such services as Airbnb or Uber.

In developed capitalist economies, but often also in less developed ones, an unbelievable amount of waste is created that remains unconsumed. Inconceivable amounts of materials and energy, i.e. natural resources are used in order to produce unutilized goods, the environmental impact of which is more than worrisome. The Hungarian ridesharing service Oszkar continuously indicates on its homepage the reduction in carbon dioxide emission due to their service offered - which on the 10 August 2016 amounted to $807179167 \mathrm{~kg}$, a practice similarly applied by such emblematic figures of sharing economy as Uber or Airbnb (see Figure 2). But at the same time, an opposite effect is created. An increase in consumption of sharing services as a result of their affordability (compared to their traditional counterparts) results in creating a greater environmental burden, regarding both transportation and recreation. Uber, for example, 
increases the number of traffic jams in cities where it is available. Exchanging used clothing, sharing tools, or bicycles constitute, on the other hand, definitely "green" sharing solutions.

Figure 2. Airbnb's estimates on sustainability measures

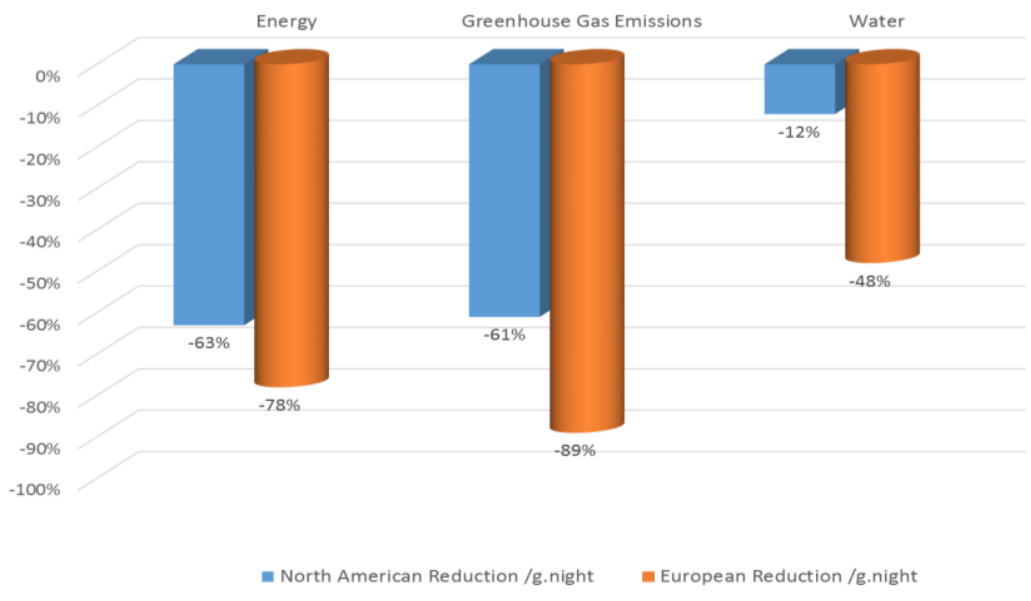

Source: http://blog.airbnb.com/environmental-impacts-of-home-sharing/

\section{2. Increasing economies of scale and scope}

Sharing is spreading quickly in various market segments - from money loans (Zopa, in the United Kingdom has 57,000 members), to lending used appliances (Open Shed in Australia), or to renting homes (Airbnb). As can be seen from the data below, a further advantage of sharing as opposed to traditional equivalents is that it may become a network of an almost limitless size, involving masses in the network of participants sharing their goods.

Airbnb may boast with 60 million users. It has 640 thousand hosts, 2 million listings in 57 thousand cities, 192 countries, and the service is used daily by an average of 500 thousand people (data from first half of 2016, see Smith 2017a). Even the largest international hotel chains or cab companies cannot come near these dimensions. "Airbnb's platform has scaled quickly in terms of users and numbers of transactions. A strong network effect has influenced the constant growth of hosts and guests. Through its platform, Airbnb has not just created new user behaviors but has changed the supply side of the hotel industry as well" (Henten - Windekilde 2016: 9). In 
comparison, Uber has 8 million users, 160 thousand drivers providing services, and have completed 2 billion rides in total so far, with the average daily use amounting to 1 million rides. Uber operates in 400 cities and 70 countries (Smith 2017b).

Similarly to other institutional entrepreneurships - from the Dutch East India Company to conglomerates - institutional entrepreneurship of sharing also extends the boundaries of transactions, both in time ${ }^{12}$ and space. At the same time, it decreases the per-unit production and transaction costs. (Horton - Zeckhauser 2016) This latter impact is much stronger in case of $21^{\text {st }}$ century institutional entrepreneurship than it was earlier. "Without the digital platforms, the transaction costs of searching, contacting, contracting, etc. would generally be much too high for such commercial markets to develop." (Henten - Windekilde 2016: 2) The decreasing costs enable to form a pricing strategy (in most cases dynamic pricing) which is advantageous for the consumers.

A further advantage of sharing in comparison with traditional service providers is that while these latter usually offer a couple of variants of their service - a few dozen, as a maximum -, services operating on a sharing basis not only have an extended network, but, consequently, they can also offer a much greater variety of services. As a result, personal needs may be satisfied more adequately by services based on sharing. Friedman (2013) underpins this statement by the following facts (cited Brian Cheskyt, the co-founder of Airbnb):

\begin{abstract}
"We have over 600 castles," he begins. "We have dozens of yurts, caves, tepees with TVs in them, water towers, motor homes, private islands, glass houses, lighthouses, igloos with Wi-Fi; we have a home that Jim Morrison used to live in; we have treehouses - hundreds of treehouses — which are the most profitable listings on our Web site per square footage. The treehouse in Lincoln, Vt., is more valuable than the main house. We have treehouses in Vermont that have had six-month waiting lists. People plan their vacation now around treehouse availability! In 2011, Prince Hans-Adam II offered his entire principality of Liechtenstein for rent on Airbnb (\$70,000 a night), 'complete with customized street signs and temporary currency'." (Friedman 2013)
\end{abstract}

The $21^{\text {st }}$ century versions of tourism can less and less be based on the uniform mass services, people are more and more attracted by variety, ie. the source of income and profit growth is

\footnotetext{
${ }^{12}$ In contrast to simple capitalist private companies, the shareholder companies survive their founders or their families, and the lifespan of the business is absolutely independent from the individuals' life courses.
} 
economies of scope (Szabó - Kocsis 2002), i.e. a combination of services offered for the masses and satisfaction of personal needs (masses, in some cases, may stand for the entire population of the Earth in principle, as in the case of Airbnb operating in 192 countries, which, as is illustrated by the above quotation, offers the satisfaction of exceptionally extreme personal needs, as well).

\subsection{Increasing flexibility}

As mentioned in Section 3, one of institutional entrepreneurship's main trumps in competition is that they offer greater flexibility in comparison with its conventional equivalents. Typical sharing services not only match special consumer needs thanks to their great variety, but also because of their availability in time, as in case of Uber, for example. The number of service providers is low in case of traditional cabs in times of day that are inconvenient for the drivers, such as late night hours, and their numbers stay below real demand, resulting in some potential customers getting no service. At the same time, Uber offers services in these periods as well. As a result of dynamic pricing, flexible harmonization of supply and demand is possible. While traditional cabs operate usually on fixed prices, Uber prices go up in busy periods, to an extent that depends on actual demand, thus reducing demand. This way the service will only be used by those customers for whom it is so important that they are ready to pay the higher prices. In other words, the match of supply and preferences on the demand side is much better in time.

Flexibility is apparent not only in the adjustment to consumer needs, but also in the personal schedule of those offering the service, i.e. the service may be regarded as a bilaterally flexible service. All aforementioned features of sharing may also be considered as combinations of some kind, as illustrated by Table 1.

Increase of flexibility is enabled be the evaluation system, which is quite characteristic for this type of entrepreneurship. Evaluation may be mutual in some cases: not only does the passenger or the guest evaluate the service provider, but the service provider also evaluates the customer. The continuous feedback of customers gives the opportunity for the service provider to quickly adjust its activity to the needs of its customer. At the same time the evaluation system works as a reputation and trust building mechanism between the two parties of transaction. 


\section{Sharing and its conventional market alternatives}

Similarly to other novel institutions, the sharing economy has a disruptive side to it - just like all new institutions; it might force out competitors offering traditional services from the market.

\subsection{Sharing in the light of traditional solutions}

As mentioned in Section 3, institutional entrepreneurs reflect on new technologies, take advantage of the competitive edges, and ride the new technological wave. In case of sharing, especially in its mixed version, Uber and Airbnb, the introduction and penetration of new ICT technologies is a key factor of success. Institutional innovations are made easier to carry out because traditional enterprises often fail to take advantage of these opportunities, they do not notice the appearance of dangerous competitors, and by the time they realize the danger, the new institution has acquired considerable market share, starting to even force them out of the market. This was typically observable in the case of Uber and Airbnb.

The institution of sharing, especially the variants classifiable as collaborative consumption, are especially decreasing the environmental burden, and foster the spread of a green attitude. In comparison with sharing, its conventional market alternatives prove to be very expensive and wasteful. As we face the threat of global warming and other environmental catastrophes day by day, it is difficult to shrug our shoulders when witnessing the mindless waste of resources and not ponder on how this could be changed. This can also be considered as a comparative advantage of sharing against conventional market solutions. As it mentioned in Section 3, the chances for institutional entrepreneurships to appear are especially big in highly monopolized sectors. This could be observed in the 1970s when conglomerates appeared, but also on the contemporary cab market, where customers encounter rigid market structures. Naturally, incumbents offering traditional services tend to attempt to maintain the status quo, and fight the spread of the new institutions with all means available. They could, however, probably be more successful in retaining their market position by adopting a different behavior. Similarly to English landlords, who became capitalists in the course of the industrial revolution, traditional 
service providers could undergo a transformation to adapt to the new environment. However, we can only see a few examples for this behavior.

Competitors offering traditional alternative services often attempt to annul the competitive advantage of these novel institutions by forcing them out through legal regulation rather than by innovating their own services. This can be witnessed in several countries - among them in Hungary, in the case of Uber or Airbnb. Fortunately, there are some good examples too. For example, in connection with Uber, two taxi companies from Budapest - although failing to radically change their services - had an application for smart phones developed, adopting this element from Uber. This way, they managed to somewhat make their customers experience something similar to what Uber offers to the users, at least in this respect. In Table 2, the characteristics of sharing-based services are contrasted with those of conventional market-based services.

A crucial problem of these types of sharing is facilitating trust among service providers and their clients. This problem is especially sharp in rental markets, given the "opportunity" renters have to misuse or destroy the flats or houses. Facilitating trust is not an easily solved problem, but in online markets different trust building mechanisms have been built in earlier, on which participants in sharing transactions can rely

Table 2. Mixed sharing and its conventional market alternatives

\begin{tabular}{|l|l|l|}
\hline \multicolumn{1}{|c|}{ Name } & \multicolumn{1}{|c}{$\begin{array}{c}\text { Current conventional } \\
\text { market solutions }\end{array}$} \\
\hline Character of institution & Market based & $\begin{array}{l}\text { Sharing Entrepreneurship } \\
\text { Combination of community based and market } \\
\text { based elements }\end{array}$ \\
\hline Technological background & $\begin{array}{l}\text { Mainly traditional industrial } \\
\text { technologies }\end{array}$ & $\begin{array}{l}\text { Application for mobile technologies, smart } \\
\text { phones, internet platforms combined with } \\
\text { traditional technologies (car, flat, etc.) }\end{array}$ \\
\hline Power-market position & $\begin{array}{l}\text { In most cases hard power, dominant } \\
\text { market players, significant market } \\
\text { share (Hargadon-Douglas 2001) }\end{array}$ & $\begin{array}{l}\text { Soft power, new entrants, market niche } \\
\text { (proximity to the client as a result of its size). } \\
\text { Resources far outnumber those of even the } \\
\text { biggest traditional service provider }\end{array}$ \\
\hline
\end{tabular}




\begin{tabular}{|c|c|c|}
\hline Transaction + production cost & High & $\begin{array}{l}\text { Low (due to the decreasing information cost, } \\
\text { search costs and the higher capacity } \\
\text { utilization }\end{array}$ \\
\hline $\begin{array}{l}\text { Social loss } \\
\text { (transactions failed) }\end{array}$ & $\begin{array}{l}\text { Big (Dahlman 1979). The less affluent } \\
\text { clients are not able to access the service }\end{array}$ & Can significantly decrease loss \\
\hline Fit of preferences, flexibility & $\begin{array}{l}\text { Gaps, inflexible, additional costs, fixed } \\
\text { prices }\end{array}$ & Corrected fit, flexibility, dynamic pricing ${ }^{13}$ \\
\hline $\begin{array}{l}\text { Growth potential (increase in } \\
\text { well-being) }\end{array}$ & Small, or none at all & $\begin{array}{l}\text { Big growth potential due to the international } \\
\text { networks }\end{array}$ \\
\hline Regulation & State (overregulation) & Reputation based + state regulation \\
\hline
\end{tabular}

Source: compiled by the author

Last, but not least, self-regulation in the sharing economy appears to be inevitable. It is more and more difficult to apply state regulation over a global economy operating within frameworks of increasing complexity. Sluggishness of state bureaucracy is in striking contrast with hectic economic changes. It is only self-regulation that may resolve this contradiction. The sharing economy is based on trust building and self-regulation, which, however, cannot mean that state regulation is altogether unnecessary. The existence of sharing, however, might also be seen as a reaction to overregulation. The strategy of states that do not live with the possibility of overregulation and only intervene to the extent that is necessary in order to cut back "wildings" might be set as a good example (Estonia is a country that follows this practice in the region).

\section{Conclusions}

The paper aimed at answering some of the questions connected to the phenomenon of institutional entrepreneurship that, despite the rapidly growing body of literature focusing on the subject, had so far remained partly unanswered. We also tried to find arguments for the relevance and timely nature of the problem.

\footnotetext{
${ }^{13}$ According to Techopedia (n.d.), "dynamic pricing is a customer or user billing mode in which the price for a product frequently rotates based on market demand, growth and other trends. It enables setting a cost for a software or Web-based product that is highly flexible in nature. Dynamic pricing is also known as real-time pricing."
} 
Institutional entrepreneurships pivot around modifying existing institutions. As this is conceptualized by the so called agency theory, the role of human activity in the construction of institutions is of key importance.

Attempts were made in the study to illustrate theoretical presumptions on institutional entrepreneurship with examples from the sharing economy. This novel phenomenon spreading like wildfire probably constitutes the most significant institutional entrepreneurship existing at present. We tried to introduce sharing in a meticulous way, from different angles, making a clear distinction between pure sharing on the one hand, void of business interests and profit orientation, and mixed versions on the other, combining community resources with platforms operating on business principles.

We also tried to answer the question whether sharing such as Uber or Airbnb established by institutional entrepreneurs may be regarded as a radically new phenomenon or it should be considered merely as a digitalized market place that technically makes the meeting of supply and demand easier. While this latter opinion does exist, we, however, tried to show how agents establishing sharing economy did not only manage to carry out technical modifications in transactions, but they also had a deep impact on economic relations, on the relationship to ownership, and on the operation of society as a whole.

New socio-economic forms always have an antecedent, they always emerge as a result of the combination of already existing elements. The most important contribution of the present article to the research of this field is that it combines two novel topics, that of institutional entrepreneurship and of sharing economy, and describes the latter in several aspects as the combination of already known factors. Institutional entrepreneurship of mixed sharing mobilizes capacities that did not use to work as capital before, thus it transfers them to "quasi capital", making social loss deriving from failed transactions avoidable, decreasing environmental and transaction costs, increasing the flexibility and growth potential of the economy. 


\section{References}

Alford, J. (2014): The Multiple Facets of Co-Production: Building on the work of Elinor Ostrom. Public Management Review 16 (3): 299-316.

Belarbi, M. (n.d.): Startup From The Bottom: Here Is How Uber Started Out. http://gulfelitemag.com/startup-bottom-uber-started/, accessed 28 June 2017.

Bockhaven, W. - Matthyssens, P. - Vandenbemt, K. (2015): Empowering the Underdog: Soft Power in the Development of Collective Institutional Entrepreneurship in Business Markets. Industrial Marketing Management 48: 174-186.

Botsman, R. - Rogers, R. (2011): What's Mine is Yours. How Collaborative Consumption Is Changing the Way We Live. London: Collins.

Brousseau, E. - Garrouste, P. - Raynaud, E. (2011): Institutional Changes: Alternative Theories and Consequences for Institutional Desingn. Journal of Economic Behavior and Organization 79 (12): 3-19.

Christensen, C. (1997/2013): The Innovator's Dilemma. The Innovator's Solution, How Will You Measure Your Life? Boston: Harvard Business Review Press.

Cramer, J. - Krueger, A. B. (2016): Disruptive Change in the Taxi Business: The Case of Uber American Economic Review: Papers - Proceedings 106 (5):177-182.

Dahlman, C. J. (1979): The Problem of Externality. The Journal of Law and Economics 22 (1): $141-162$.

Dean, T. J. (2016): New Venture Formations in United States Manufacturing: The Role of Industry Environments. New York: Routledge.

DiMaggio, P. (1988): Interest and Agency in Institutional Theory. In Zucker, L. (ed.): Instititutional Patterns and Organizations. Cambridge (Mass.): Ballinger Publishing Company, pp. 3-21.

DiMaggio, P. J. - Powell, W. W. (1983): The Iron Cage Revisited: Institutional Isomorphism and Collective Rationality in Organizational Fields. American Sociological Review 48(2): 147-160.

Drori, I. - Landau, D. (2011): Vision and Change in Institutional Entrepreneurship. The Transformation from Science to Commercialization. New York: Berghahn Books.

Dubois, E. - Schor, J. - Carfagna. L. (2014): Connected Consumption: a Sharing Economy Takes Hold. Rotman Management, Spring.

Eckhardt, G. M. - Bardh, F. (2015): The Sharing Economy Isn't About Sharing at All. Harvard Business Review, January.

Friedman, T. L. (2013): Welcome to the 'Sharing Economy'. New York Times, July 20. 
Garud, R. - Jain, S. - Kumaraswamy, A. (2002). Institutional Entrepreneurship in the Sponsorship of Common Technological Standards: The Case of Sun Microsystems and Java. Academy of Management Journal 45(1):196-214.

Garud, R. - Hardy, C. - Maguire, S. (2007): Institutional Entrepreneurship as Embedded. Agency: An Introduction to the Special Issue. Organization Studies 28(7): 957-969.

Gibson-Graham, J. K. (2003): An Ethics of the Local. Rethinking Marxism. A Journal of Economics, Culture - Society 15(1): 49-74.

Greenwood, R. - Suddaby, R., - Hinings, C. R. (2002): Theorizing Change: The Role of Professional Associations in the Transformation of Institutional Fields. Academy of Management Journal 45: 58-80.

Hamari, J. - Sjöklint, M. - Ukkonen, A. (2016): The Sharing Economy: Why People Participate in Collaborative Consumption. Journal of the Association for Information Science and Technology 67(9): 2047-2059.

Hargadon, A. - Douglas, Y. (2001): When Innovations Meet Institutions: Edison and the Design of the Electric Light. Administrative Science Quarterly 46(3): 476-501.

Hayek, F. A. (1988): The Fatal Conceit. Chicago: University of Chicago Press.

Henten, A. H. - Windekilde, I. M., (2016): Transaction Costs and the Sharing Economy. Info 18(1): 1-15.

Horton, J. J - Zeckhauser, R. J. (2016): Owning, Using and Renting: Some Simple Economics of the Sharing Economy. NBER Working Paper No. 22029.

Hu, H. - Huang, T. - Zeng, Q - Zhang, S. (2016): The Role of Institutional Entrepreneurship in Building Digital Ecosystem: A Case Study of Red Collar Group (RCG). International Journal of Information Management 36(3): 496-499.

Kingston, C. - Caballero, G. (2009): Comparing Theories of Institutional Change. Journal of Institutional Economics 5(2): 151-180.

Lakshman, C. - Akhter, M. (2015): Microfoundations of Institutional Change: Contrasting Institutional Sabotage to Entrepreneurship. Canadian Journal of Administrative Sciences 32(3): 160-176.

Lawrence, T. - Suddaby: R. (2006): Institutions and Institutional Work. In Clegg, S. - Hardy, C. - Lawrence, T. - Nord, W. R. (eds): Handbook of Organization Studies London: Sage Publications, pp. 211-254.

Leca, B. - Battilana, J. - Boxenbaum, E. (2008): Agency and Institutions: A Review of Institutional Entrepreneurship. Harvard Business School Working Paper No. 08-096.

Morgan, B - Kuch, D. (2015): Radical Transactionalism: Legal Consciousness, Diverse Economies, and the Sharing Economy. Journal of Law and Society 42(4): 556-587.

North, D. (1990): Institutions, Institutional Change and Economic Performance. Cambridge: Cambridge University Press. 
Noble Topf, L. (2014): Wheelcar Wisdom. iUniverse.

OECD (2011): Together for Better Public Services: Partnering with Citizens and Civil Society. Paris: OECD.

Ostrom, E. (2009): Beyond Markets and States: Polycentric Governance of Complex Economic Systems. Nobel Prize Lecture, 8 December.

Ostrom, V. - Ostrom, E. (1977): Public Goods and Public Choices In. Savas, E. S (ed.): Alternatives for Delivering Public Services: Toward Improved Performance. Boulder, CO: Westview Press.

Raffaely, R. - Glynn, M. A. (2015): Institutional Innovation. Novel, Useful and Legitimate. In: Shalley, C. E. - Hitt, M. A. - Zhou, J. (eds): The Oxford Handbook of Creativity, Innovation, and Entrepreneurship. Oxford: Oxford University Press, 407-420.

Rifkin, J. (2014): The Zero Marginal Cost Society: The Internet of Things, the Collaborative Commons, and the Eclipse of Capitalism. New York: St. Martin's Press.

Samuelson, P. A. (1976): Economics. New York: McGrawHill.

Scott, W. R. (2008): Institutions and Organizations. Thousand Oaks, CA: SAGE Publications.

Scott, W. R. (2010): The Mediating Role of Institutions. In: Sine, W, D. - David, R. J. (eds): Institutions and Entrepreneurship. Bingley, UK: Emerald Group Publishing.

Shane, S. - Venkataraman, S. (2000): The Promise of Entrepreneurship as a Field of Research. Academy of Management Review 25: 217-226.

Shiller, J. (2005): Behavioral Economics and Institutional Innovation. Cowles Foundation for Research in Economics. Yale University. New Haven, Connecticut.

Smith, C. (2017a): 90 Amazing Airbnb Statistics and Facts. http://expandedramblings.com/index.php/airbnb-statistics/, accessed 28 June 2017.

Smith, C. (2017b): 67 Amazing Uber Statistics and Facts. http://expandedramblings.com/index.php/uber-statistics/, accessed 28 June 2017.

Szabó, K. - Kocsis, É. (2002): Digitális paradicsom vagy falanszter? A személyes tömegtermelés [Digital capitalism or phalanstery?]. Budapest: Aula Kiadó.

Szabó, K. - Hámori, B. (2006): Információgazdaság. Digitális kapitalizmus vagy új gazdasági rendszer? [Information Economy]. Budapest: Akadémiai Kiadó.

Tracey, P. - Phillips, N. -Jarvis, O. (2011): Bridging Institutional Entrepreneurship and the Creation of New Organizational Forms: A Multilevel Mode. Organization Science 22(1): 6080 .

Techopedia (n.d.) Dynamic Pricing https://www.techopedia.com/definition/29600/dynamicpricing, accessed 28 June 2017.

Williamson, O. E. (1975): Markets and Hierarchies: Analysis and Anti-trust Implication. New York: Free Press. 
Williamson, O. E. (1985): The Economic Institutions of Capitalism. New York: The Free Press. 